medRxiv preprint doi: https://doi.org/10.1101/2020.03.28.20046003; this version posted March 30, 2020. The copyright holder for this preprint (which was not certified by peer review) is the author/funder, who has granted medRxiv a license to display the preprint in perpetuity.

It is made available under a CC-BY-ND 4.0 International license.

\title{
1 Presence of concurrent sarcoid-like granulomas indicate better survival in cancer
} 2 patients

Mukunthan Murthi ${ }^{1}$, Keiichiro Yoshioka ${ }^{2}$, Jeong Hee $\mathrm{Cho}^{3}$, Sixto Arias ${ }^{1}$, Elio Danna ${ }^{1}$, 5 Greg Holt $^{1,4}$, Koichiro Tatsumi ${ }^{2}$, Takeshi Kawasaki ${ }^{2}$, and Mehdi Mirsaeidi ${ }^{1,4}$

${ }^{1}$ Division of Pulmonary and Critical Care, University of Miami, Miami, FL, USA

8 'Department of Respirology, Graduate School of Medicine, Chiba University, Chiba,

9 Japan

$10{ }^{3}$ Department of Pathology, University of Miami, Miami, FL, USA

$11{ }^{4}$ Section of Pulmonary, Miami VA Healthcare System, Miami, FL, USA

\section{Correspondence author:}

Dr. Mehdi Mirsaeidi

18

Division of Pulmonary and Critical Care, University of Miami, Miami, FL, USA.

21 Email: msm249@med.miami.edu.

\section{Take home message:}

25 Our findings suggest that patients with underlying malignancy who develop sarcoidosis

26 and sarcoid-like reactions have a lower risk of stage 4 metastatic disease and better

27 survival compared to patients who do not develop such granulomatous reactions.

Authors' contributions:

- Mukunthan Murthi, Keiichiro Yoshioka conducted chart review and collected data, data analysis, literature review and helped in manuscript preparation.

- Jeong Hee Cho provided melanoma dataset and helped to develop first draft of manuscript.

- Sixto Arias, Elio Danna, Greg Holt reviewed EBUS procedures and helped in analyzing and discussing results and manuscript preparation. 
medRxiv preprint doi: https://doi.org/10.1101/2020.03.28.20046003; this version posted March 30, 2020. The copyright holder for this preprint (which was not certified by peer review) is the author/funder, who has granted medRxiv a license to display the preprint in perpetuity. It is made available under a CC-BY-ND 4.0 International license .

37 - Koichiro Tatsumi, and Takeshi Kawasaki assisted in reviewing the subjects' data

38 accuracy, data analysis, and in manuscript preparation.

39 - Mehdi Mirsaeidi conducted literature review, designed the study, conducted

40 exploratory analysis, performed data analysis, and manuscript preparation

41

42

43

44

45

46

47

48

49

50

51

52

53

54

55

56 
medRxiv preprint doi: https://doi.org/10.1101/2020.03.28.20046003; this version posted March 30, 2020. The copyright holder for this preprint (which was not certified by peer review) is the author/funder, who has granted medRxiv a license to display the preprint in perpetuity.

It is made available under a CC-BY-ND 4.0 International license .

\section{Abstract:}

58 Introduction: An increased risk of sarcoidosis and sarcoid-like reactions in subjects with

59 a history of malignancy has been suggested. We assessed the incidence and clinical

60 characteristics of cancer patients with biopsies containing sarcoid-like granulomas on

61 cancer metastasis and patient survival.

62

63 Methods: This is a retrospective, multicenter, observational study involving patients who

64 underwent Endobronchial Ultrasound (EBUS) at the University of Miami Hospital, Miami

65 Veterans Affairs Medical Center in the USA and Chiba University in Japan. Subjects with

66 a confirmed diagnosis of cancer and who subsequently developed granulomas in

67 different organs were enrolled. The study was registered at Clinicaltrial.gov

68 (NCT03844698).

69

70 Results: One hundred and thirty-three patients met the study's criteria. The most

71 common primary cancer sites were the skin (22.5\%), breast (20.3\%), and lymph node

72 (LN) (12.8\%). Twenty-four (18\%) patients developed sarcoidal granulomas within 1 year

73 of cancer diagnosis, 54(40.6\%) between 1 and 5 years and 49(36.8\%) after 5 years.

74 Imaging showed possible sarcoidal granulomas in lymph nodes in 51 cases (38.3\%) and

75 lung tissue and mediastinal lymph nodes in 73 cases (54.9\%); some parenchymal

76 reticular opacity and fibrosis were found in 5(3.7\%) and significant parenchymal fibrosis

77 in $2(1.5 \%)$ subjects. According to logistic regression analysis, the frequency of

78 metastatic cancer was significantly lower in patients with sarcoidal granulomas than in

79 controls. Moreover, multivariate Cox proportional hazard analysis showed a significant

80 survival advantage in those with sarcoidal granuloma.

81 
medRxiv preprint doi: https://doi.org/10.1101/2020.03.28.20046003; this version posted March 30, 2020. The copyright holder for this preprint (which was not certified by peer review) is the author/funder, who has granted medRxiv a license to display the preprint in perpetuity. It is made available under a CC-BY-ND 4.0 International license .

82 Conclusion: Sarcoidal granulomas are uncommon pathology findings in cancer

83 patients. There is a significant association between the presence of granulomas and

84 reduced metastasis and increased survival. Further study is warranted to understand the 85 protective mechanism involved. 
medRxiv preprint doi: https://doi.org/10.1101/2020.03.28.20046003; this version posted March 30, 2020. The copyright holder for this preprint (which was not certified by peer review) is the author/funder, who has granted medRxiv a license to display the preprint in perpetuity.

It is made available under a CC-BY-ND 4.0 International license .

\section{Introduction}

88 Sarcoidosis is a multisystem granulomatous disease that predominantly affects the lung

89 but can be seen in any organ system[1]. The fundamental abnormality in sarcoidosis is

90 the development of pathological structures known as non-caseating granulomas [2]

91 consisting of collections of macrophages and epithelioid cells surrounded by

92 lymphocytes and fibroblasts. Although the etiology of such granuloma formation in

93 sarcoidosis remains unclear, it is believed to be due to an abnormal host immune

94 response to an unknown antigen in genetically susceptible individuals.

95

96 Multiple studies have demonstrated an increased risk of cancer following sarcoidosis. In

97 a retrospective study of nearly 9000 sarcoidosis patients, Askling et al. reported an

98 elevated risk of cancer with a standardized incidence of $1.3(\mathrm{Cl}-1.2-1.4)[3]$. In a recent

99 meta-analysis of over 25,000 patients, there was a relative risk of $1.19(95 \% \mathrm{Cl}, 1.07$ -

100 1.32) for the development of all types of invasive cancers in patients with sarcoidosis[4].

101

102 Less is known about the development of sarcoidosis after the onset of malignancy.

103 Patients with an underlying malignancy develop noncaseating epithelioid cell

104 granulomas in regional and distant lymph nodes and/or parenchyma of various organs

105 [5]. Given the characteristic enlargement of lymph nodes associated with sarcoidosis,

106 the clinical and radiological features of these conditions mimic metastatic cancer and

107 require biopsy. To date, only a few studies have analyzed the occurrence of sarcoidosis

108 after cancer diagnosis and most are case reports. We previously described the

109 increased incidence of sarcoidosis among subjects with breast cancer in our registry[6].

110 Whether the presence of sarcoid-like granulomas affects survival if developed after 
medRxiv preprint doi: https://doi.org/10.1101/2020.03.28.20046003; this version posted March 30, 2020. The copyright holder for this preprint (which was not certified by peer review) is the author/funder, who has granted medRxiv a license to display the preprint in perpetuity.

It is made available under a CC-BY-ND 4.0 International license.

111 cancer onset is difficult to assess as different studies have reported conflicting results[7-

$11211]$

113

114 This study aimed to compare the clinicopathological characteristics and outcomes in

115 cancer patients with and without sarcoid-like granulomas in biopsy specimens. sarcoid-

116 like granulomas are thought to develop from a persistent immune reaction, we

117 postulated that cancer patient's granulomatous reactions indicate a robust immune

118 response and may provide a survival advantage.

119

120

\section{Methods}

122

123 Study Design

124

125 We conducted a multicenter, retrospective observational study of over 1600 subjects at

126 the University of Miami Hospital, Miami Veterans Affairs Medical Center (VAMC) in

127 Florida, the United States, and Chiba University in Chiba, Japan. The study was

128 approved by the local Institutional Review Boards (IRBs) with a waiver of informed

129 consent. For better transference, we herein refer to both sarcoidosis and sarcoid

130 reactions occurring in cancer patients as "sarcoidal granuloma". We identified each case

131 of sarcoidal granuloma by manually sorting through prospectively collected datasets of

132 patients who underwent EBUS-TBNA for suspected cancer diagnosis at the University of

133 Miami, Miami VAMC and Chiba University. A dataset consisting of prospectively

134 collected data for melanoma patients from a single provider at the University of Miami

135 was also used. 
medRxiv preprint doi: https://doi.org/10.1101/2020.03.28.20046003; this version posted March 30, 2020. The copyright holder for this preprint (which was not certified by peer review) is the author/funder, who has granted medRxiv a license to display the preprint in perpetuity.

It is made available under a CC-BY-ND 4.0 International license.

137 Inclusion and exclusion criteria

138

139 Any patient with a pathology finding of sarcoidal granuloma during or after cancer

140 diagnosis was included in the study. Subjects found to have sarcoidal granuloma before

141 the diagnosis of cancer were excluded. Other causes of granulomatous disease were

142 excluded by mycobacterial and fungal staining of pathology samples and culture, review

143 of the subject history and follow-up. For each patient, demographic data, including age,

144 sex and ethnicity, were collected. Details on cancer as well as sarcoidal granulomas

145 were also obtained. All cancers were staged according to the American Joint Committee

146 on Cancer (AJCC) guidelines.

148 Survival analysis

150 Subject group survival was compared to a control group to determine the effect of

151 sarcoidal granulomas on cancer survival. For the ten most commonly occurring cancers

152 among our subjects (breast, bladder, prostate, and pancreatic cancers, lymphoma, RCC,

153 melanoma, colon carcinoma, sarcoma), controls with the same cancer diagnosis were

154 identified and chosen randomly based on the absence of sarcoidal granuloma up to a

155 ratio of 3:1. For both groups, only patients with up-to-date follow-up and for whom their

156 death was documented in the medical records were included for survival analysis. For

157 subjects with more than one cancer diagnosis, cancer that was diagnosed closest to the

158 time of granuloma diagnosis was used for case and control matching.

159

160 Statistical analysis

161 
medRxiv preprint doi: https://doi.org/10.1101/2020.03.28.20046003; this version posted March 30, 2020. The copyright holder for this preprint (which was not certified by peer review) is the author/funder, who has granted medRxiv a license to display the preprint in perpetuity.

It is made available under a CC-BY-ND 4.0 International license .

162 Categorical variables are described as counts and percentages; their distribution was

163 compared using odds ratios and tested using the chi-squared test and Cochran-Mantel-

164 Haenszel test or exact tests, as indicated. Continuous variables were analyzed with

165 independent sample t-tests (two-tailed). Cox proportional hazard analysis was performed

166 for all cancers to identify whether potentially confounding variables affect survival

167 independently. The selection of variables was based on a review of the literature with

168 regards to factors affecting survival among cancer patients. For the four common

169 cancers among our subjects, i.e., lung and breast cancers, melanoma and lymphoma,

170 we performed the log-rank test to predict statistically significant differences in survival.

171 Kaplan-Meier curves were generated to illustrate the ordinality of any differences found.

172 We also applied logistic regression analysis to examine the relationship between various

173 clinical factors and the likelihood of stage 4 metastatic disease. All analyses were carried

174 out using SPSS software for Windows, version 26. For all results, significance was

175 considered at $p<0.05$.

176

177

178 Results

179

180 Patient characteristics

181

182 After reviewing 1546 electronic medical records at the University of Miami, 212 patients

183 had sarcoidal granulomas on pathology reports (Figure 1) and 1219 had a history of

184 cancer. 101 (8.3\%) patients developed sarcoidal granulomas after cancer diagnosis.

185 Chiba University contributed 32 subjects for analysis producing a total of 133 subjects

186 for the study. Among the 133 subjects, 61 (45.9\%) were male and $72(54.1 \%)$ female. 
medRxiv preprint doi: https://doi.org/10.1101/2020.03.28.20046003; this version posted March 30, 2020. The copyright holder for this preprint (which was not certified by peer review) is the author/funder, who has granted medRxiv a license to display the preprint in perpetuity.

It is made available under a CC-BY-ND 4.0 International license .

187 The ethnic distribution included 35 (26.3\%) Asians, 48 (36.1\%) European-Americans, 14

188 (10.5\%) African Americans, 31 (23.3\%) Latinos and 5 (3.7\%) of mixed ethnicity. The

189 mean age of the subjects was 64.5 years (SD- 22 to 86 years). Table 1 summarizes the

190 subjects' cancer and sarcoidosis characteristics.

191

192 Thirty-nine (29.3\%) subjects had a history of more than one cancer before the sarcoidal

193 granuloma diagnosis. The most common primary cancer sites were the skin $(30 ; 22.5 \%)$,

194 breast $(27 ; 20.3 \%)$, and lymph node (LN) (17; 12.8\%). Regarding cancer stages at the

195 time of sarcoidal granuloma diagnosis, 24 cases (15.8\%) were stage 1, 17 cases (12\%)

196 were stage 2,18 cases (12.7\%) were stage 3 and 12 cases $(7.5 \%)$ were stage 4 .

198 Fifty-four patients (40.6\%) were treated with chemotherapy, 38 patients (28.6\%) were

199 treated with radiation and 91 patients (68.4\%) underwent surgery prior to sarcoidal

200 granuloma diagnosis. The commonly used chemotherapy agents were doxorubicin (15;

$20111.3 \%)$, cisplatin (11; 8.2\%) and cyclophosphamide (11;8.2\%). Other commonly used

202 agents are listed in Table 1. More than half of the subjects (61.4\%) developed

203 granulomas within 5 years of their cancer diagnosis. The median interval between

204 cancer and sarcoidosis diagnoses was 3 years (mean 6 years, range 1-37 years).

205

206

207 Radiological, pathological and laboratory characteristics of subjects with confirmed 208 granulomas

210 The presence of sarcoidal granulomas in cancer patients led us to define possible

211 sarcoidosis staging by assessing chest imaging via CT or PET/CT. A total of $79 \%$ of

212 patients had mediastinal and/or hilar lymph nodes greater than $1 \mathrm{~cm}$ at the time of 
medRxiv preprint doi: https://doi.org/10.1101/2020.03.28.20046003; this version posted March 30, 2020. The copyright holder for this preprint (which was not certified by peer review) is the author/funder, who has granted medRxiv a license to display the preprint in perpetuity.

It is made available under a CC-BY-ND 4.0 International license .

213 sarcoidal granuloma diagnosis. The commonly enlarged lymph nodes on imaging were 214 station 7 (85 [64\%]), 4R (73 [54.9\%]), and 2R (50 [37.6\%]). The most common 215 parenchymal lesion was the presence of nodules (in 73 subjects; $54.9 \%$ ), followed by 216 GGO (in 13; 9.7\%), reticular opacities (in 9; 6.7\%), atelectasis (in 8; 6\%) and 217 bronchiectasis (in 3; 2.3\%). The mean size of pulmonary nodules was $9.7 \mathrm{~mm}$ (range 2$21830 \mathrm{~mm})$. Thirty-one (23.3\%) patients had extra-thoracic lymph nodes $>10 \mathrm{~mm}$ or with

219 SUV $>2.5$. Based on Scadding criteria at the time of diagnosis, if defined them as 220 sarcoidosis, sarcoidosis staging was as follows: stage 1, 38.3\%; stage 2, 54.9\%; stage $2213,3.7 \%$; and stage 4, 1.5\%.

222

223 The most common intrathoracic LNs diagnosed with granuloma were station 7 (51.9\%), 224 4R (23.3\%), 11L (15.8\%) and 11R (15\%). Thirty-one (23.3\%) subjects had granulomas 225 in the parenchyma. Twenty-six (19.5\%) had extra-thoracic granulomas, with skin 10 $226(7.5 \%)$ and liver $5(3.7 \%)$ being the most common sites. Fourteen (10.5\%) subjects had 227 necrotizing granulomas on pathology. In total, the frequency of granulomas in our 228 dataset was $8.3 \%$.

230 Pulmonary function test (PFT) results were available for 61 subjects, 35 (26.3\%) of 231 which were normal. In those with impaired function, $12(9 \%)$ had restrictive disease, and $23214(10.5 \%)$ had an obstructive pattern. ACE levels were available for 54 patients, and 233 the median value was $25.35 \mathrm{U} / \mathrm{L}$ (Mean=31.92). CRP was available for 52 patients, and 234 it was elevated in $21(15.7 \%)$. More than half of our subjects $(68 ; 51.2 \%)$ were 235 asymptomatic at the time of sarcoidal granuloma diagnosis. In symptomatic patients, the 236 most common symptoms were dyspnea (in $20 ; 15 \%$ ), cough (in $18 ; 13.5 \%$ ) and fatigue 237 (in $16 ; 12 \%$ ). 
medRxiv preprint doi: https://doi.org/10.1101/2020.03.28.20046003; this version posted March 30, 2020. The copyright holder for this preprint (which was not certified by peer review) is the author/funder, who has granted medRxiv a license to display the preprint in perpetuity.

It is made available under a CC-BY-ND 4.0 International license.

241 We also compared the subject's nationality to determine whether there is any clinical

242 difference between Japanese or American patients. Japanese subjects were less likely

243 than Americans to have stage 2, 3 and 4 sarcoidosis (OR 0.31 [0.13-0.72], p-

244 value $=0.007$ and were less likely to develop sarcoidal granulomas within 5 years of

245 cancer diagnosis (OR-0.31 [0.13-0.72] $p$-value $=0.006)$.

246

247 Association between sarcoidosis granulomas and cancer stage 4 (metastasis)

249 We compared the characteristics of cancer between the case and control groups. Ten $250(22.2 \%)$ of the subjects in the sarcoidal granuloma group had stage 4 disease compared

251 to $72(57.6 \%)$ subjects in the control group. Figure 2 depicts the forest plot of the

252 estimates and 95\% confidence intervals obtained by logistic regression analysis

253 representing independent factors associated with stage 4 disease in patients with

254 cancer. The presence of granuloma $(\mathrm{OR}=0.216$ [0.097-0.483], $\mathrm{p}<0.0001)$ and male

255 gender $(0.500$ [0.258-0.968], $\mathrm{p}=0.04)$ was associated with a lower incidence of stage 4

256 disease. Of note, there were no significant differences in treatment modality

257 (chemotherapy, radiotherapy, MAB, surgery) between the subjects with and without

258 stage 4 disease. Moreover, we did not find any impact due to the race of the subjects on

259 the cancer stage.

260

261 Survival analysis

262

263 The average number of years of follow-up for the cancer patients with and without

264 sarcoidal granulomas was 7.58 years $(S D=6.90)$ and 6.07 years $(S D=6.49)$, respectively 
medRxiv preprint doi: https://doi.org/10.1101/2020.03.28.20046003; this version posted March 30, 2020. The copyright holder for this preprint (which was not certified by peer review) is the author/funder, who has granted medRxiv a license to display the preprint in perpetuity.

It is made available under a CC-BY-ND 4.0 International license .

$265(p=0.284)$. Patients with both sarcoidal granulomas and cancer showed greater 2-year

$266(\mathrm{OR}=5.37 \quad[1.35-21.4], \quad \mathrm{p}=0.017)$, 4-year $(\mathrm{OR}=4.49 \quad[1.55-12.98], \quad p=0.006), 6$-year

$267(\mathrm{OR}=6.70$ [2.42-18.61], $\mathrm{p}=<0.0001)$ and 10-year (OR=7.10 [2.80- 18.00], $\mathrm{p}=<0.0001)$

268 survival times compared to those with cancer without the presence of sarcoidal

269 granuloma (Table 2). However, there was no significant difference in survival between

270 the two groups beyond 10 years $(p=0.095)$.

271

272 Likely due to the decrease in stage IV cancer diagnoses, we observed a statistically

273 significant difference in the treatment administered, with fewer subjects having sarcoidal

274 granuloma being treated with chemotherapy $(p=0.001)$, monoclonal antibody therapy

275 (MAB) $(p=0.002)$ and radiotherapy $(p=0.038)$ compared to controls. There was a

276 significant difference in the number of Asian and Latino subjects between the two

277 groups, as the control group was obtained from the University of Miami database, which

278 serves a predominantly Latino population with a relatively small Asian community.

279

280 Similarly, a multivariate Cox proportional hazards regression model adjusted for

281 potentially confounding baseline demographic and clinical characteristics, including age,

282 sex, ethnicity, cancer treatment and cancer stage, showed increased survival among

283 subjects with sarcoidal granuloma and cancer compared to those with cancer alone

284 (Figure 3).

285

286 Kaplan-Meier survival curves along with the log-rank test comparing cancer patients with

287 and without sarcoidal granulomas for the most commonly occurring cancers (breast,

288 lung, lymphoma and melanoma) in our dataset revealed only a significant survival

289 advantage for those with lung cancer $(p=0.011)$ (Figure 4$)$, but not for melanoma

$290(p=0.210)$, lymphoma $(p=0.114)$ or breast cancer $(p=0.054)$. 
medRxiv preprint doi: https://doi.org/10.1101/2020.03.28.20046003; this version posted March 30, 2020. The copyright holder for this preprint (which was not certified by peer review) is the author/funder, who has granted medRxiv a license to display the preprint in perpetuity.

It is made available under a CC-BY-ND 4.0 International license.

\section{Discussion}

295 The current study found that $8.3 \%$ of cancer patients had sarcoidal granuloma in 296 pathology samples. Patients with skin, breast, and prostate cancers and lymphoma were

297 more likely to develop sarcoidal granuloma. Of most importance, this study found a

298 decreased incidence of stage 4 cancer in patients with sarcoidal granulomas compared

299 to matched controls and led to a significant survival advantage at 2, 4, 6 and 10 years.

301 Despite the wide range of cancers reported for individuals with sarcoidal granulomas, 302 breast malignancy is the most commonly occurring cancer in most studies. A study by

303 Keiss et al. investigated 64 patients with sarcoidal granuloma after cancer found $17 \%$ of

304 the subjects had breast cancer[12]. Furthermore, Butt et al. reviewed 30 subjects with

305 sarcoidal granuloma following cancer, of whom 33\% had breast cancer[13]. A similar

306 predominance of breast cancer has been recorded by several other authors[14-16], and

307 this observation is consistent with our data.

308

309 The mean age of onset of sarcoidosis among our subjects was 64.5 years. This is in

310 agreement with multiple studies describing the occurrence of sarcoidal granuloma in

311 cancer patients is $>50$ years instead of the typical ages of sarcoidosis patients who are

312 between 20 and 39 years[7, 12, 15-17]. As suggested by Grados et al.[18] and Hunt et

313 al.[14], the reason may be that cancer occurs more commonly in those of an older age.

314 This discrepancy in age of diagnosis suggests that the malignancy may be providing the 315 antigen that fuels the sarcoid-like granulomatous reaction. 
medRxiv preprint doi: https://doi.org/10.1101/2020.03.28.20046003; this version posted March 30, 2020. The copyright holder for this preprint (which was not certified by peer review) is the author/funder, who has granted medRxiv a license to display the preprint in perpetuity.

It is made available under a CC-BY-ND 4.0 International license .

317 Our findings also suggest a decreased incidence of stage 4 metastatic disease in

318 patients with sarcoidal granulomas. Grados et al. in their analysis also showed that none

319 of 12 subjects with sarcoidal granuloma presented with metastatic disease[18]. These

320 findings may suggest a protective role for sarcoidal granulomas with regard to

321 metastasis in cancer patients. This effect may be due to cancer cells being prevented

322 from evading activated immune cells when there is a high tendency to develop

323 granulomas. Further investigation of this speculation may lead to new therapeutic agents

324 for cancer immunotherapy.

325

326 Overall, the prognostic value of sarcoidal granuloma in cancer requires further

327 investigation. A recent study by Steinfort et al. among subjects with NSCLC indicated a

328 significant cancer-free survival in those with sarcoidal granuloma $(n=8)$ who had no

329 recurrence of the disease compared to $44 \%$ of controls who had recurrence at a median

330 interval of 11 months after surgery[7]. Similarly, in their study of survival among 19

331 patients with lung cancer and coexisting granulomatous inflammation, Dagaonkar et al.

332 observed a 3 -year survival rate of $21 \%$ compared to $6 \%$ in those without

333 granulomas[19]. Regardless, several other studies failed to reveal any significant

334 difference in prognosis in patients with sarcoidal granulomas[8, 20]. One major

335 drawback of these studies is the relatively small sample sizes and univariate analysis of

336 survival, which makes it challenging to predict prognosis accurately.

338 In our study, the overall survival for all patients with cancer and sarcoidal granuloma was

339 significantly higher than that of the controls when analyzed using the Cox proportional

340 hazards regression model. Significance was not reached in Kaplan-Meier analysis for

341 survival for every individual cancer, except for lung cancer, which was probably due to 
medRxiv preprint doi: https://doi.org/10.1101/2020.03.28.20046003; this version posted March 30, 2020. The copyright holder for this preprint (which was not certified by peer review) is the author/funder, who has granted medRxiv a license to display the preprint in perpetuity.

It is made available under a CC-BY-ND 4.0 International license .

342 the limited sample size; however, the trend for improved survival was apparent. The

343 current data indicated a lower percentage of stage 4 disease in subjects with sarcoidal

344 granuloma compared to controls, and this, in turn, might be the reason for the observed

345 increase in survival.

346

347 Earlier studies have suggested chemotherapeutic agents as potentially inducing 348 sarcoidal granulomas[21, 22]. We find this suggestion unlikely, as less than half of our

349 subjects were treated with chemotherapy and not one chemotherapeutic agent was used

350 in more than $12 \%$.

351

352 One question that arises is the mechanism of granuloma formation. The immunology of 353 sarcoidal reactions occurring in cancer patients remains undiscovered. Nonetheless, it 354 has been suggested that these sarcoidal granulomas could be an immune reaction to 355 cancer cells[13]. For this to be true, the antigen sustaining the granulomas must be 356 derived from cancer cells. We suggest that vimentin may be a possible candidate 357 antigen. Vimentin, a member of the intermediate filament family of proteins, has been 358 identified in BAL samples from sarcoidosis subjects[23, 24], and the T-cells derived from 359 these BAL samples have revealed identical T-cell receptor sequences. Interestingly, 360 modeling of these sequences with HLA-DR3 protein sequences showed an ideal fit for a 361 vimentin peptide[25]. In addition, macrophages, an essential part of sarcoid granulomas, 362 have also been shown to secrete vimentin when activated[26]. The Kveim-Siltzbach 363 agent, which was historically used in the diagnosis of sarcoidosis, contained vimentin, 364 further implicating a role in sarcoidal granuloma formation[27].

366 Although vimentin is a major component of the cytoskeleton of mesenchymal cells, its 367 expression is upregulated in various cancers of epithelial origin. Vimentin expression has 
medRxiv preprint doi: https://doi.org/10.1101/2020.03.28.20046003; this version posted March 30, 2020. The copyright holder for this preprint (which was not certified by peer review) is the author/funder, who has granted medRxiv a license to display the preprint in perpetuity.

It is made available under a CC-BY-ND 4.0 International license .

368 also been reported in malignant lymphomas[28]. Its role in the metastatic cascade has

369 also been well documented [29]. It is possible that vimentin from the primary tumor or

370 metastatic cell triggers an immune response similar to sarcoidosis in genetically

371 susceptible individuals, resulting in the formation of noncaseating granulomas. Currently,

372 no studies assessing the role of vimentin in cancer-related sarcoid reactions have been

373 conducted to corroborate this hypothesis.

374

375 Ideally, larger international prospective studies to analyze the incidence and determine

376 the prognostic value of sarcoidal granulomas more accurately should be conducted. It is

377 also essential to obtain a deeper understanding of the pathophysiology of cancer-related

378 granulomas. Immune profiling of granulomas to assess the presence or absence of

379 various receptors and markers, such as vimentin, maybe the first step. If these

380 granulomas are indeed antitumor responses to metastasizing cells, studies to

381 molecularly detect neoplastic cells within granulomas using techniques such as PCR can

382 be performed[30].

383

384 Limitations

385

386 Our study has all the limitations pertinent to retrospective studies. Despite being a 387 relatively large study on this subject, we were unable to perform multivariate Cox 388 survival analysis for every individual cancer due to the small subgroup sample size. One 389 of our datasets consisted of melanoma patients only (140 subjects), which might be the 390 reason for the higher number of subjects with a history of melanoma.

\section{Conclusion}


medRxiv preprint doi: https://doi.org/10.1101/2020.03.28.20046003; this version posted March 30, 2020. The copyright holder for this preprint (which was not certified by peer review) is the author/funder, who has granted medRxiv a license to display the preprint in perpetuity. It is made available under a CC-BY-ND 4.0 International license.

395 The findings of our study suggest that cancer patients who develop sarcoidal

396 granulomas have a survival advantage with lower rates of stage 4 disease. Thus, finding

397 sarcoidal granulomas could serve as a prognostic biomarker. Although the exact

398 mechanism of granuloma formation is unknown, they are likely to be an immune

399 response to neoplastic components and if proven, could also serve as a therapeutic

400 biomarker for immunotherapy. Larger case-control studies are required to confirm and

401 further assess the increased survival reported herein and evaluate the presence of

402 possible cancer-related biomarkers in these granulomas via molecular-based studies.

403

404

405 Financial support:

406

407 No financial support was received for this study

408

409

410

411

412

413

414 
medRxiv preprint doi: https://doi.org/10.1101/2020.03.28.20046003; this version posted March 30, 2020. The copyright holder for this preprint (which was not certified by peer review) is the author/funder, who has granted medRxiv a license to display the preprint in perpetuity. It is made available under a CC-BY-ND 4.0 International license .

415

416

417

418

419

420

421

422

423

424

425

426

427

428

429

430

431

432

433

434

435

436

437

438

439

440

441

442

443

444

445

446

447

448

449

450

451

452

453

454

455

456

457

458

459

\section{References:}

1. Ma Y, Gal A, Koss MN. The pathology of pulmonary sarcoidosis: update. Seminars in diagnostic pathology 2007: 24(3): 150-161.

2. $\quad$ Soler P, Basset F, Bernaudin JF, Chretien J. MORPHOLOGY AND DISTRIBUTION OF THE CELLS OF A SARCOID GRANULOMA: ULTRASTRUCTURAL STUDY OF SERIAL SECTIONS. Annals of the New York Academy of Sciences 1976: 278(1): 147-160.

3. ASKLING J, GRUNEWALD J, EKLUND A, HILLERDAL G, EKBOM A. Increased Risk for Cancer Following Sarcoidosis. American Journal of Respiratory and Critical Care Medicine 1999: 160(5): 1668-1672.

4. Bonifazi M, Bravi F, Gasparini S, La Vecchia C, Gabrielli A, Wells AU, Renzoni EA. Sarcoidosis and cancer risk: systematic review and meta-analysis of observational studies. Chest 2015: 147(3): 778-791.

5. Cohen PR, Kurzrock R. Sarcoidosis and malignancy. Clinics in Dermatology 2007: 25(3): 326-333.

6. Schweitzer M, Salamo 0, Mirsaeidi M, Holt G, Donna E, Pardinas Gutierrez M, Asharhan L. Increased risk of sarcoidosis among breast cancer patients; Breast cancer - sarcoidosis syndrome. European Respiratory Journal 2017: 50(suppl 61): PA361.

7. Steinfort DP, Tsui A, Grieve J, Hibbs ML, Anderson GP, Irving LB. Sarcoidal reactions in regional lymph nodes of patients with early stage non-small cell lung cancer predict improved disease-free survival: a pilot case-control study. Human Pathology 2012: 43(3): 333-338.

8. Tomimaru Y, Higashiyama M, Okami J, Oda K, Takami K, Kodama K, Tsukamoto Y. Surgical results of lung cancer with sarcoid reaction in regional lymph nodes. Jpn J Clin Oncol 2007: 37(2): 90-95.

9. O'Connell MJ, Schimpff SC, Kirschner RH, Abt AB, Wiernik PH. Epithelioid Granulomas in Hodgkin Disease: A Favorable Prognostic Sign? JAMA 1975: 233(8): 886-889.

10. Sacks EL, Donaldson SS, Gordon J, Dorfman RF. Epithelioid granulomas associated with Hodgkin's disease: clinical correlations in 55 previously untreated patients. Cancer 1978: 41(2): 562-567.

11. Brincker H. Sarcoid reactions and sarcoidosis in Hodgkin's disease and other malignant lymphomata. Br J Cancer 1972: 26(2): 120-123.

12. Kiess AP, Wang H, Travis WD, Yahalom J. Sarcoid in cancer patients: clinical characteristics and associated disease status. Sarcoidosis Vasc Diffuse Lung Dis 2015: 32(3): 200-207.

13. Butt S, Alzebdeh R, Kable T, Soubani A0. Non-caseating granulomas in patients after the diagnosis of cancer: Clinical characteristics and outcome. Sarcoidosis, vasculitis, and diffuse lung diseases : official journal of WASOG / World Association of Sarcoidosis and Other Granulomatous Disorders 2011: 28: 44-49. 14. Hunt BM, Vallières E, Buduhan G, Aye R, Louie B. Sarcoidosis as a benign cause of lymphadenopathy in cancer patients. The American Journal of Surgery 2009: 197(5): 629-632. 
medRxiv preprint doi: https://doi.org/10.1101/2020.03.28.20046003; this version posted March 30, 2020. The copyright holder for this preprint (which was not certified by peer review) is the author/funder, who has granted medRxiv a license to display the preprint in perpetuity. It is made available under a CC-BY-ND 4.0 International license .

460 15. Arish N, Kuint R, Sapir E, Levy L, Abutbul A, Fridlender Z, Laxer U, Berkman 461 N. Characteristics of Sarcoidosis in Patients with Previous Malignancy: Causality or 462 Coincidence? Respiration 2017: 93(4): 247-252.

463 16. Spiekermann C, Kuhlencord M, Huss S, Rudack C, Weiss D. Coexistence of 464 sarcoidosis and metastatic lesions: A diagnostic and therapeutic dilemma. Oncol Lett 465 2017: 14(6): 7643-7652.

466 17. Iannuzzi MC, Rybicki BA, Teirstein AS. Sarcoidosis. New England Journal of 467 Medicine 2007: 357(21): 2153-2165.

468 18. Grados A, Ebbo M, Bernit E, Veit V, Mazodier K, Jean R, Coso D, Aurran469 Schleinitz T, Broussais F, Bouabdallah R, Gravis G, Goncalves A, Giovaninni M, Sève P, Chetaille B, Gavet-Bongo F, Weitten T, Pavic M, Harlé J-R, Schleinitz N. Sarcoidosis Occurring After Solid Cancer: A Nonfortuitous Association: Report of 12 Cases and Review of the Literature. Medicine 2015: 94(28): e928-e928.

19. Dagaonkar RS, Choong CV, Asmat AB, Ahmed DBA, Chopra A, Lim AYH, Tai DYH, Kor AC, Goh SK, Abisheganaden J, Verma A. Significance of coexistent granulomatous inflammation and lung cancer. J Clin Pathol 2017: 70(4): 337-341. 20. Kamiyoshihara M, Hirai T, Kawashima O, Ishikawa S, Morishita Y. Sarcoid reactions in primary pulmonary carcinoma: report of seven cases. Oncol Rep 1998: 5(1): $177-180$.

21. Merchant TE, Filippa DA, Yahalom J. Sarcoidosis following chemotherapy for Hodgkin's disease. Leuk Lymphoma 1994: 13(3-4): 339-347. Mimicking Progression of Lymphoma on FDG PET/CT. Clin Nucl Med 2017: 42(9): 702-703. RA, Grunewald J, Ytterberg AJ. Approach for Identifying Human Leukocyte Antigen (HLA)-DR Bound Peptides from Scarce Clinical Samples. Molecular \&amp; Cellular Proteomics 2016: 15(9): 3017-3029.

24. Wahlström J, Dengjel J, Persson B, Duyar H, Rammensee H-G, Stevanović S, Eklund A, Weissert R, Grunewald J. Identification of HLA-DR-bound peptides presented by human bronchoalveolar lavage cells in sarcoidosis. The Journal of Clinical Investigation 2007: 117(11): 3576-3582.

25. Wahlström J, Dengjel J, Winqvist 0, Targoff I, Persson B, Duyar H, Rammensee H-G, Eklund A, Weissert R, Grunewald J. Autoimmune T cell responses to antigenic peptides presented by bronchoalveolar lavage cell HLA-DR molecules in sarcoidosis. Clinical Immunology 2009: 133(3): 353-363.

497 26. Mor-Vaknin N, Punturieri A, Sitwala K, Markovitz DM. Vimentin is secreted by activated macrophages. Nat Cell Biol 2003: 5(1): 59-63. Wells AU, Kon OM, Wickremasinghe M, Mitchell D, Weeks ME, Lalvani A. Proteomic Analysis of Kveim Reagent Identifies Targets of Cellular Immunity in Sarcoidosis. PLoS One 2017: 12(1): e0170285-e0170285.

504 28. Sarker AB, Akagi T, Yoshino T, Hoshida Y, Takahashi K, Horie Y. Expression of vimentin and epithelial membrane antigen in human malignant lymphomas. Acta

505 Pathol Jpn 1990: 40(8): 581-587. 
medRxiv preprint doi: https://doi.org/10.1101/2020.03.28.20046003; this version posted March 30, 2020. The copyright holder for this preprint (which was not certified by peer review) is the author/funder, who has granted medRxiv a license to display the preprint in perpetuity.

It is made available under a CC-BY-ND 4.0 International license .

506 29. Kidd ME, Shumaker DK, Ridge KM. The role of vimentin intermediate

507 filaments in the progression of lung cancer. Am J Respir Cell Mol Biol 2014: 50(1): 1-

5086.

509 30. Sanchez-Cespedes M, Esteller M, Hibi K, Cope FO, Westra WH, Piantadosi S,

510 Herman JG, Jen J, Sidransky D. Molecular Detection of Neoplastic Cells in Lymph

511 Nodes of Metastatic Colorectal Cancer Patients Predicts Recurrence. Clinical Cancer

512 Research 1999: 5(9): 2450-2454.

513

514

515

516

517

518

519

520

521

522

523

524

525

526

527

528

529

530

531

532

533

534

535

536

537

538

539

540

541

542

543

544

545

546

547

548

549

550

551

552

553

554

555 
medRxiv preprint doi: https://doi.org/10.1101/2020.03.28.20046003; this version posted March 30, 2020. The copyright holder for this preprint (which was not certified by peer review) is the author/funder, who has granted medRxiv a license to display the preprint in perpetuity. It is made available under a CC-BY-ND 4.0 International license .

556

557

558

559

560

561

562

563

564

565

566

567

568

569

570

571

572

573

574

575

576

577

578

579

580

581

582

583

584

585

586

587

588

589

590

591

592

593

594

595

596

597

598

599

600

601

602

603

\section{Figure Legends:}

Figure 1: Flowchart showing the selection of cases of cancer with sarcoidal granuloma.

Figure 2: Logistic regression with stepwise elimination; p-value from Hosmer and Lemeshow goodness-of-fit test $=0.497$. The rhombus shape indicates the odds ratio $(\mathrm{OR})$, and the vertical line indicates the confidence interval $(\mathrm{Cl})$. The arrow indicates that the $95 \% \mathrm{Cl}$ is outside the range shown.

Figure 3: Multivariate Cox proportional hazard analysis of survival of cancer patients with and without sarcoidal granulomas.

Figure 4: Kaplan-Meier survival analysis showing the survival curve for the most common cancers among controls and cases- Melanoma (a), Lymphoma (b), Lung cancer (c) and Breast cancer (d). The curves illustrate the proportion of subjects at each time point who were alive. The $p$-value was calculated by the log-rank test. 
604 Table 1: Characteristics of patients with cancer and sarcoidosis.

605

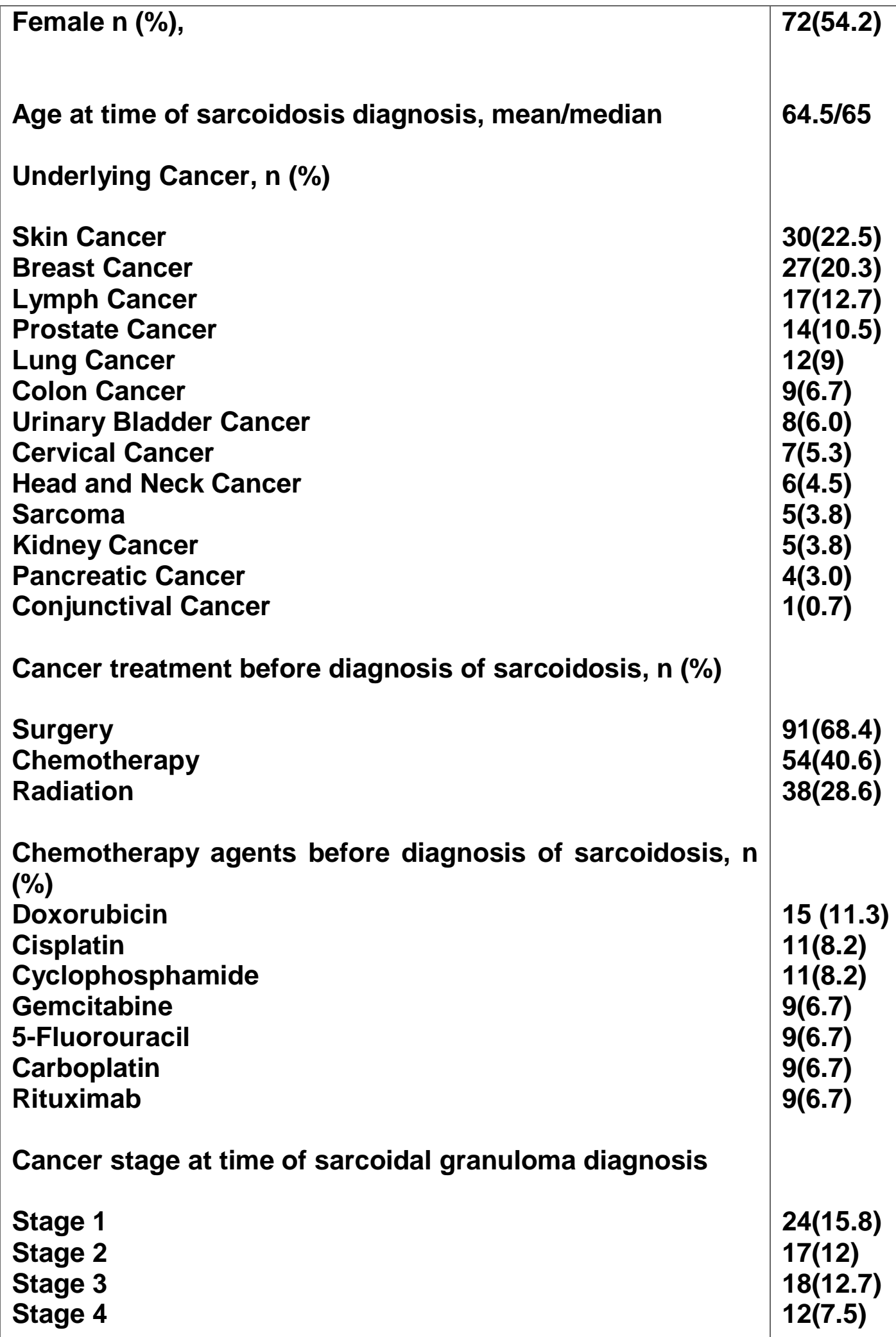




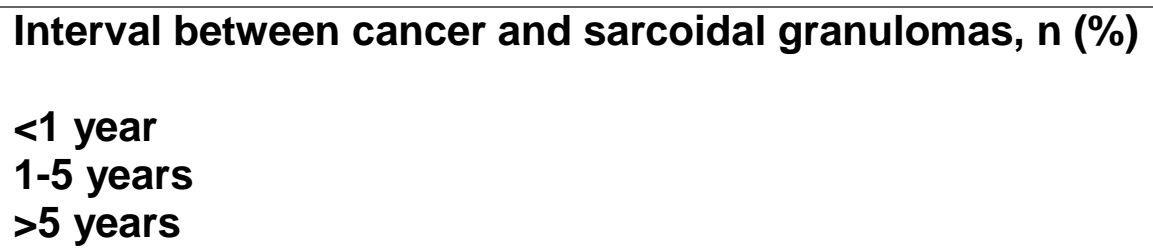

Most common symptom at time of sarcoidosis diagnosis, n (\%)

Dyspnea

Cough

Fatigue

Smoking, n (\%)

Current

Past

Never smoker

Mean number of years of smoking

Sarcoidosis stage at the time of diagnosis, $\mathbf{n}(\%)$

Stage 1

Stage 2

Stage 3

Stage 4
24(18.9)

54(42.5)

49(38.5)

20(15)

18(13.5)

16(12)

7(5.2)

48(36.1)

76(57.1)

28.5

51(38.3)

73(54.9)

5(3.7)

2(1.5) 
medRxiv preprint doi: https://doi.org/10.1101/2020.03.28.20046003; this version posted March 30, 2020. The copyright holder for this preprint (which was not certified by peer review) is the author/funder, who has granted medRxiv a license to display the preprint in perpetuity.

It is made available under a CC-BY-ND 4.0 International license .

624 Table 2: Comparison of cancer subjects with and without sarcoidal granuloma.

625

\begin{tabular}{|c|c|c|c|c|}
\hline Variable & Cancer only & $\begin{array}{l}\text { Cancer and } \\
\text { granuloma }\end{array}$ & p-value & OR $(95 \% \mathrm{Cl})$ \\
\hline Alive $<2$ years & $20(46.5 \%)$ & $14(82.4 \%)$ & 0.017 & $5.37(1.35-21.4)$ \\
\hline Alive $<4$ years & $40(50 \%)$ & $23(82.1 \%)$ & 0.006 & $4.49(1.55-12.98)$ \\
\hline Alive $<6$ years & $48(51.1 \%)$ & $35(87.5 \%)$ & $<0.0001$ & $6.70(2.42-18.61)$ \\
\hline $\begin{array}{ll}\text { Alive } & <10 \\
\text { years } & \end{array}$ & 57 (51.4\%) & $45(88.2 \%)$ & $<0.0001$ & $7.10(2.80-18.00)$ \\
\hline $\begin{array}{ll}\text { Alive } & >10 \\
\text { years } & \end{array}$ & $16(69.6 \%)$ & 15 (93.8\%) & 0.095 & $6.56(0.72-59.85)$ \\
\hline $\begin{array}{l}\text { Bladder } \\
\text { Cancer }\end{array}$ & $7(5.2 \%)$ & $3(4.5 \%)$ & 0.819 & $0.85(0.21-3.40)$ \\
\hline Breast Cancer & $37(27.7 \%)$ & $15(22.4 \%)$ & 0.426 & $0.76(0.38-1.50)$ \\
\hline Colon Cancer & $13(6.5 \%)$ & $7(5.2 \%)$ & 0.316 & $1.79(0.58-5.54)$ \\
\hline Lung Cancer & $30(22.4 \%)$ & $10(14.9 \%)$ & 0.215 & $0.61(0.28-1.33)$ \\
\hline Lymphoma & $15(11.2 \%)$ & $10(14.9 \%)$ & 0.451 & $1.40(0.59-3.30)$ \\
\hline Melanoma & $18(13.4 \%)$ & $6(9 \%)$ & 0.359 & $0.63(0.24-1.68)$ \\
\hline $\begin{array}{l}\text { Pancreatic } \\
\text { Cancer }\end{array}$ & $4(3 \%)$ & $3(4.5 \%)$ & 0.589 & $1.52(0.33-7.01)$ \\
\hline $\mathrm{RCC}$ & $8(6 \%)$ & $3(4.5 \%)$ & 0.662 & $0.74(0.19-2.88)$ \\
\hline Sarcoma & $2(1.5 \%)$ & $3(4.5 \%)$ & 0.222 & $3.09(0.50-18.98)$ \\
\hline $\begin{array}{l}\text { Prostate } \\
\text { Cancer }\end{array}$ & $6(4.4 \%)$ & $8(11.9 \%)$ & 0.059 & $2.89(0.96-8.71)$ \\
\hline $\begin{array}{l}\text { Cancer Stage } \\
1,2 \text { and } 3\end{array}$ & $53(42.4 \%)$ & 35 (77.8\%) & $<0.0001$ & $4.76(2.16-10.45)$ \\
\hline $\begin{array}{l}\text { Cancer Stage } \\
4\end{array}$ & $72(57.6 \%)$ & $10(22.2 \%)$ & $<0.0001$ & $0.21(0.10-0.46)$ \\
\hline Male & $53(39.6 \%)$ & $32(47.8 \%)$ & 0.268 & $1.40(0.77-2.52)$ \\
\hline $\begin{array}{l}\text { European- } \\
\text { American }\end{array}$ & $56(41.8 \%)$ & $23(34.3 \%)$ & 0.308 & $0.73(0.40-1.34)$ \\
\hline Hispanic & $57(42.5 \%)$ & $17(25.4 \%)$ & 0.019 & $0.46(0.24-0.88)$ \\
\hline $\begin{array}{l}\text { African } \\
\text { American }\end{array}$ & $17(12.7 \%)$ & $12(17.9 \%)$ & 0.323 & $1.50(0.67-3.36)$ \\
\hline Asian & $2(1.5 \%)$ & $12(17.9 \%)$ & 0.001 & $14.40(3.12-66.48)$ \\
\hline Surgery & $86(67.2 \%)$ & $39(63.9 \%)$ & 0.659 & $0.87(0.46-1.64)$ \\
\hline Radiotherapy & $69(53.9 \%)$ & $23(37.7 \%)$ & 0.038 & $0.52(0.28-0.97)$ \\
\hline Chemotherapy & $90(70.3 \%)$ & $28(45.9 \%)$ & 0.001 & $0.36(0.19-0.67)$ \\
\hline MAB & $55(43.0 \%)$ & $12(19.7 \%)$ & 0.002 & $0.33(0.16-0.67)$ \\
\hline
\end{tabular}

$626 \mathrm{OR}=$ Odds ratio, $\mathrm{Cl}=$ Confidence interval, $\mathrm{RCC}=$ Renal cells carcinoma, $\mathrm{MAB}=$ Monoclonal 627 antibody therapy 


\section{Survival Function at mean of covariates}

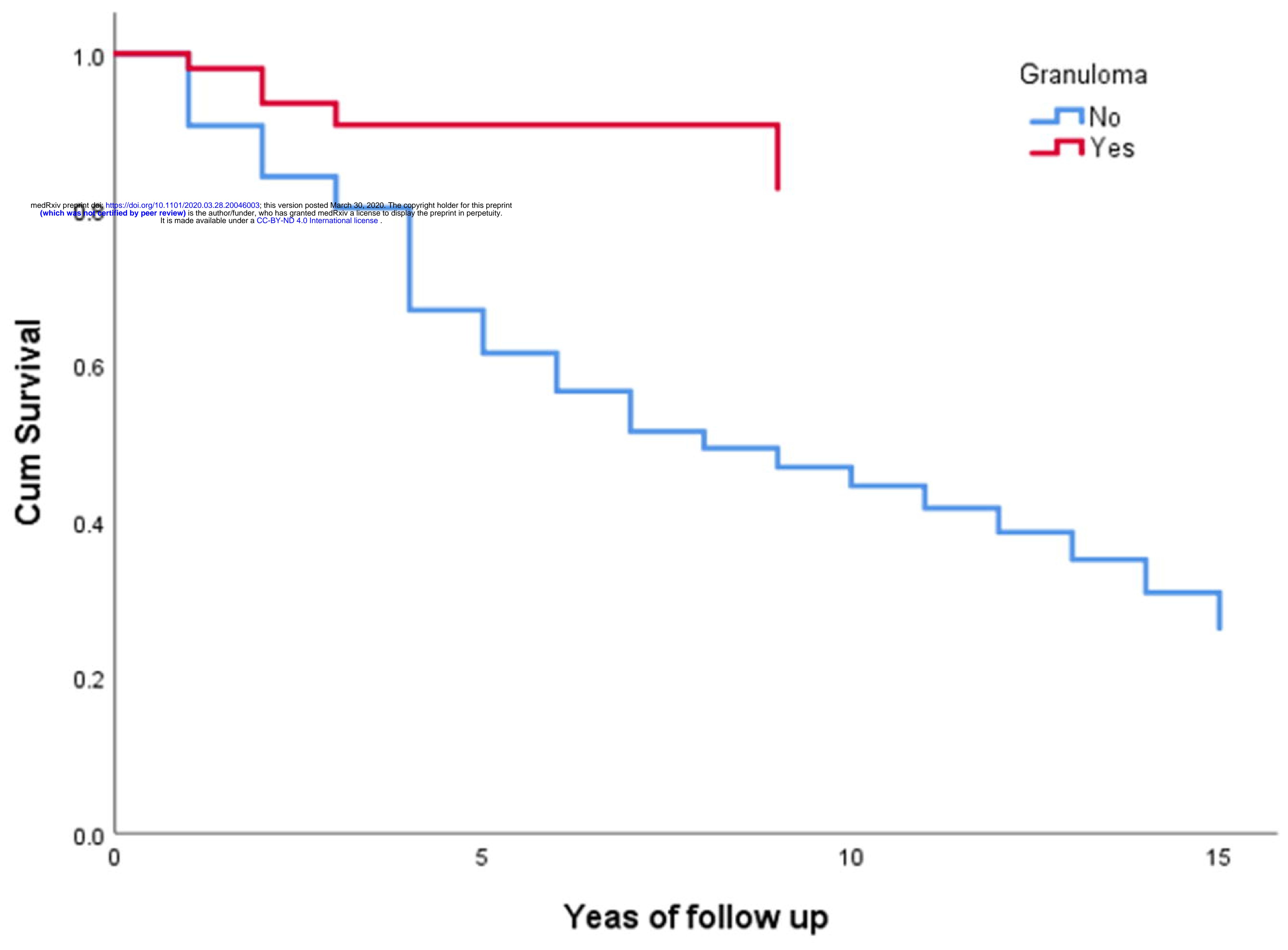


Number of patients in database 1604

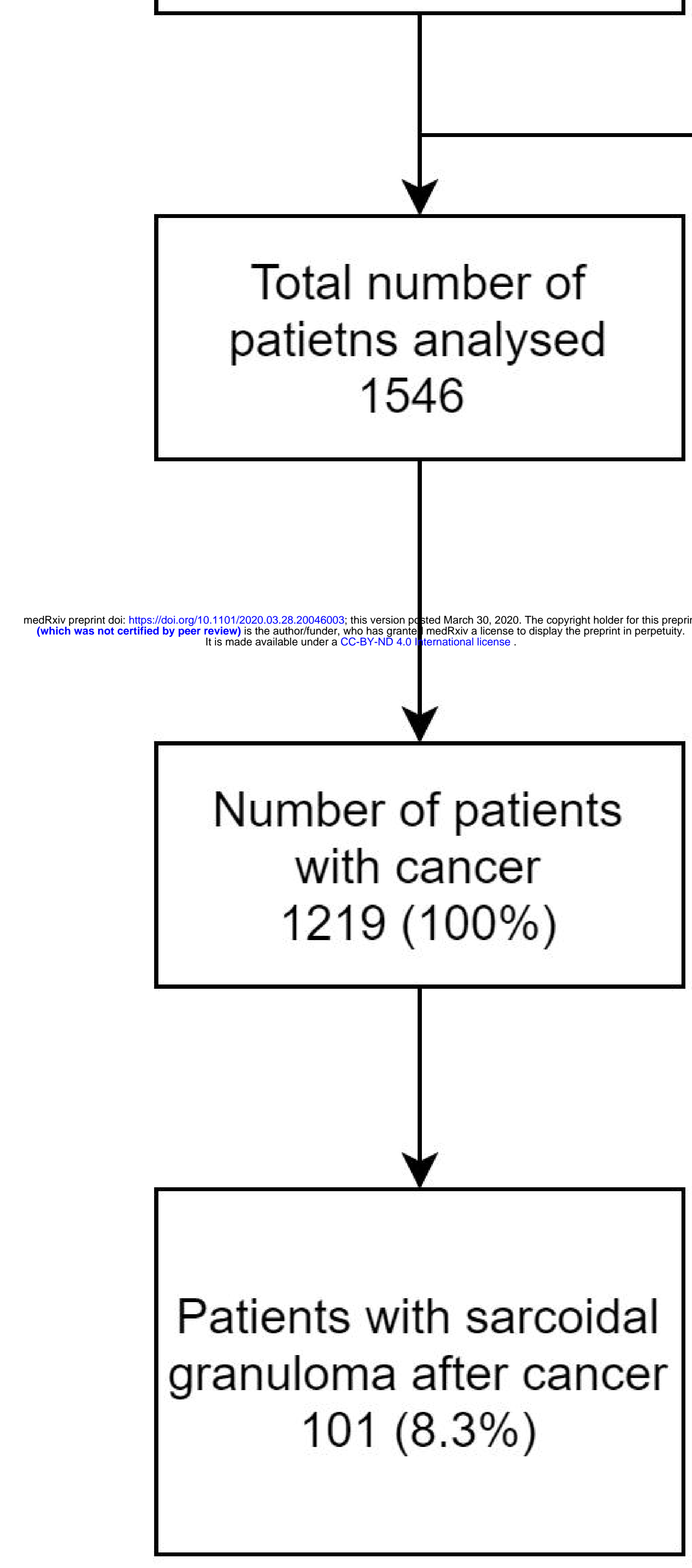

Clinical data unavailable 58 


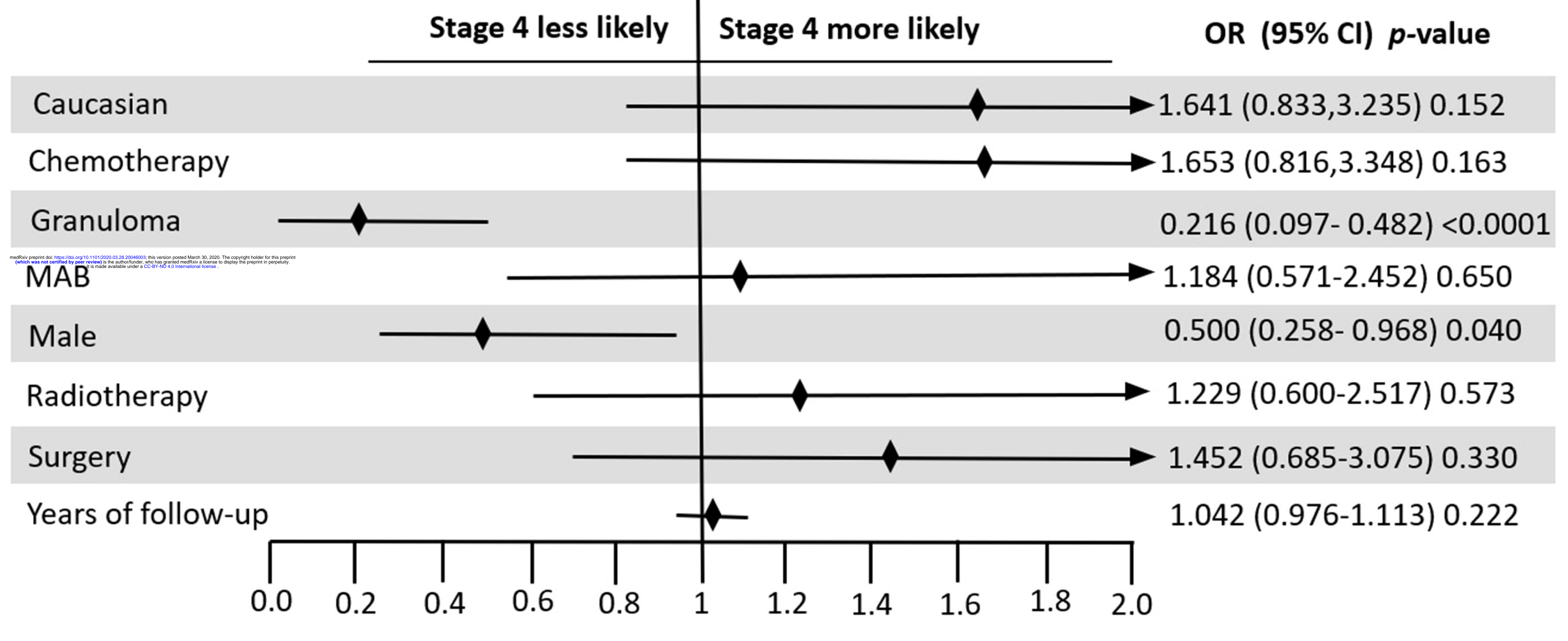

Odds Ratio and 95\% Confidence Intervals 